\title{
PURUBORÁ: ANALISANDO A HISTÓRIA, O "RESSURGIMENTO" E A RESISTÊNCIA DE UM POVO INDÍGENA DA AMAZÔNIA
}

ANATÁLIA DAIANE DE OLIVEIRA ${ }^{1}$

UFMT

MARLI LÚCIA TONATTO ZIBETTI ${ }^{2}$

UNIR

\begin{abstract}
RESUMO: $O$ presente artigo tem como objetivos: a) apresentar discussões teóricas em torno das denominações utilizadas para designar grupos indígenas que foram considerados extintos e são designados como "ressurgidos", "emergentes" elou "resistentes"; b) descrever e analisar aspectos da história, "ressurgimento" e resistência do povo Puruborá, um grupo étnico que teve sua identidade negada pela Fundação Nacional do Índio (Funai) na década de 1990 e posteriormente reconhecida por este órgão em 2003, e que atualmente luta pelo fortalecimento dessa identidade, revitalização da sua cultura e demarcação do seu território tradicional. Os dados foram obtidos em pesquisa desenvolvida na Aldeia Aperoi, no município de Seringueiras, estado de Rondônia. Trata-se de um estudo do tipo etnográfico que utilizou, como instrumento para produção dos dados, análise documental, observação participante, diário de campo e entrevistas, orientando-se teoricamente por autores do campo da educação, da psicologia e da antropologia. A análise foi realizada por meio da triangulação dos dados produzidos pelos diferentes instrumentos. Os resultados indicam tratar-se de um povo resistente, que vive um momento histórico, político e social favorável à revitalização, (re)construção e fortalecimento de sua identidade indígena.
\end{abstract}

PALAVRAS-CHAVE: povo puruborá; história; ressurgimento; resistência; identidade.

ABSTRACT: This article aims to: a) present theoretical discussions about the terms used to designate indigenous groups that were considered extinct and are designated as "resurrected", "emerging" and/or "resistant"; b) describe and analyze aspects of the history, "resurgence" and resistance of the Puruborá people, an ethnic group that had their identity denied by the Fundação Nacional do Índio (Brazilian governmental protection agency for the indigenous peoples) in the 1990s and later recognized by the agency in 2003, which currently struggle for the strengthening of their identity, revitalization of their culture and demarcation of their

\footnotetext{
1 Doutoranda em Educação pelo Universidade do Mato Grosso (UFMT). Pedagoga e mestre em Psicologia pela Universidade Federal de Rondônia (UNIR). Pesquisadora do Grupo Amazônico de Estudos e Pesquisas em Psicologia e Educação (GAEPPE) e do Grupo de Pesquisas de Educação na Amazônia (GPEA). Participante do Grupo de Pesquisas sobre Trabalho e Educação (GEPTE). E-mail: anataliadaiane@ hotmail.com.

${ }^{2}$ Doutora em Psicologia Escolar e do Desenvolvimento Humano pela Universidade de São Paulo (USP). Professora da graduação e do mestrado em Psicologia da Universidade Federal de Rondônia (UNIR). Líder do GAEPPE, vice-líder do Grupo Psicologia Escolar e Educacional: processos de escolarização e atividade profissional em uma perspectiva crítica do Instituto de Psicologia da USP. E-mail: marlizibetti@gmail.com .
} 
traditional territory. The data was obtained from research conducted in the Aperoi Village (city of Seringueiras, state of Rondônia). It is an ethnographic study that used as tools for production data document analysis, participant observation, field journaling and interviews, guided theoretically by authors from the fields of education, psychology and anthropology. The analysis was performed through the triangulation of data produced by different instruments. The results indicate that this is a resilient group of people living in a historic, political and social context that favors the revitalization, (re)building and strengthening of their indigenous identity.

KEYWORDS: Puruborá people; history; resurgence; resistance; identity.

\section{Introdução}

As discussões sobre os indígenas "ressurgidos", "emergentes" e "resistentes", particularmente desde o final do século XX, nas diferentes regiões do Brasil, em especial no Nordeste, têm sido um assunto polêmico. Como mencionado por Prezia e Hoornaert (2000), a população não indígena fica "surpresa" com os povos indígenas "emergentes", por alguns terem pele escura e cabelo crespo, enquanto outros são claros e até loiros, ou seja, por não apresentarem as características físicas dos indígenas "clássicos".

De acordo com Amorim (2003 e 2010), os traços físicos estão estreitamente ligados à persistente imagem produzida e propagada pelos meios de comunicação, em que se mantêm as descrições dos primeiros cronistas, viajantes etc., que viam e descreviam "o índio" e não as populações indígenas em suas diversidades e particularidades culturais, étnicas e históricas.

O presente artigo tem como objetivo discutir a polêmica existente entre os termos "ressurgidos", "emergentes" e "resistentes", utilizados para designar grupos indígenas que foram considerados extintos e voltaram a apresentar-se como povo que busca seu reconhecimento étnico. Com a revisão de estudos que discutem os referidos termos, descrevemos e analisamos aspectos da história, "ressurgimento" e resistência do povo Puruborá, um grupo étnico que teve sua identidade negada pela Fundação Nacional do Índio (Funai) na década de 1990, sendo posteriormente reconhecida por este órgão em 2003, e que 
atualmente luta pelo fortalecimento dessa identidade, revitalização da sua cultura e demarcação do seu território tradicional.

Este texto foi elaborado a partir de pesquisa desenvolvida na propriedade rural particular denominada pelos Puruborá de Aldeia Aperoi, localizada às margens da BR 4293, no município de Seringueiras ${ }^{4}$, estado de Rondônia.

Teoricamente o texto está sustentado em estudos desenvolvidos no campo da educação, da psicologia e da antropologia. Os dados de campo são oriundos de estudo do tipo etnográfico e os instrumentos utilizados para obtenção e produção dos dados foram: análise documental, observação participante, diário de campo e entrevistas (semiestruturadas) com cinco participantes, sendo eles: Hozana ${ }^{5}$, cacique do povo Puruborá; Valdinei, chefe de Núcleo de Educação Escolar Indígena; professora Gisele e os professores Mário e Deivid.

A análise dos dados foi realizada conforme orientação de Bogdan e Biklen (1994), buscando-se, por meio da leitura e releitura do material, na triangulação dos dados, responder aos objetivos do presente estudo.

Este trabalho está organizado em duas partes. Na primeira, discutimos teoricamente os termos "ressurgidos", "emergentes" e "resistentes", definindo e compreendendo os argumentos dos autores para a utilização de cada um deles, bem como apresentando nossos argumentos para denominar o grupo étnico Puruborá como um povo ressurgido e resistente. Na segunda parte, descrevemos e analisamos um pouco da história desse povo indígena, destacando sua "ressurgência", ocorrida na década de 2000, e as ações empreendidas pelo grupo em favor da revitalização de sua identidade. Por fim, tecemos as considerações finais sustentadas nas discussões

\footnotetext{
${ }^{3}$ Rodovia federal que liga alguns municípios do estado de Rondônia à BR 364, entre eles: Presidente Médici, Alvorada do Oeste, São Miguel do Guaporé, Seringueiras, São Francisco do Guaporé, São Domingos e Costa Marques.

${ }^{4}$ Seringueiras é um município do estado de Rondônia criado pela Lei 370, de 13 de fevereiro de 1992, constituído por meio de áreas desmembradas dos municípios de São Miguel do Guaporé e Costa Marques. O nome do município se deu porque a bacia hidrográfica do Rio São Miguel é uma grande produtora de borracha, produto da seringueira (Hevea brasilensis) (SILVA FILHO, 1995).

${ }_{5}^{5}$ Destacamos que os nomes Hozana, Valdinei, Gisele, Mário e Deivid não são fictícios e foram utilizados mediante suas autorizações, pois seria contraditório, em um artigo que discute exatamente o reconhecimento, o ressurgimento e a resistência, ocultar o nome de pessoas que são protagonistas de suas histórias, sendo todas elas indígenas puruborá, exceto Valdinei, que não é indígena.
} 
desenvolvidas no presente artigo.

Utilizaremos neste texto a linguagem não sexista, inspirada em Freire (1993), quando afirma que a existência de uma linguagem machista e, consequentemente, discriminatória é um problema ideológico e não gramatical. Nesse sentido, no decorrer do artigo, leitores e leitoras identificarão trechos como: "das e dos indígenas", as e os Puruborá, entre outros.

\section{Ressurgidos, emergentes ou resistentes? discutindo os termos e sua interface com a identidade indígena}

As primeiras investigações acerca das e dos indígenas "ressurgidos, emergentes e/ou resistentes" foram realizadas no Nordeste, entre as quais se encontram as de Arruti (1995 e 1997), Oliveira (1998), Oliveira Filho (1999a), Amorim (2003 e 2010) e Albuquerque (2012). Posteriormente, foram realizadas pesquisas em outros estados do Brasil, entre eles Goiás (PORTELA, 2006) e Minas Gerais (ARAÚJO, 2011).

A história dos e das indígenas brasileiros(as) é permeada de proibições (da própria história indígena, de suas identidades, de seus territórios, de suas culturas etc.), o que contribuiu para que no Brasil se criasse, sustentasse e reproduzisse o mito da "extinção" desses povos (ARRUTI, 1995 e 1997; AMORIM, 2003 e 2010; PORTELA, 2006; ARAÚJO, 2011).

Neste sentido, de acordo com Arruti, estamos assistindo a

[...] uma performática negação das expectativas que viciaram nosso olhar em perceber os grupos indígenas caminhando sempre sobre a linha reta que leva da fase áurea, anterior ao contato, para a de decadência, durante $\mathrm{o}$ contato e, finalmente para o indefectível desfecho que é a extinção (ARRUTI, 1995, p. 57).

Posteriormente, este mesmo autor (1997) afirma que o mito da "extinção" dos povos indígenas está relacionado à questão da "mistura", "miscigenação" e/ou "mestiçagem" desses povos com os "nacionais" (ARRUTI, 1997, p. 16), por meio de casamentos e laços de compadrio. 
Para ele, na questão nordestina,

como o diagnóstico era invariavelmente o de total "mistura" da população aldeada com os "nacionais", os aldeamentos eram considerados extintos e aquelas comissões (ou uma equipe formada após o fim dos seus trabalhos) voltavam para proceder à sua repartição em lotes que deveriam, segundo a letra da lei, ser distribuídos entre os antigos aldeados e entre nacionais (ARRUTI, 1997, p. 16, destaques no original).

Segundo Oliveira (1998), o termo "índios misturados" é merecedor de uma atenção diferenciada, uma vez que se envolvem valores, estratégias de ação e expectativas das pessoas envolvidas nessa situação. Para o autor, muitos se utilizam dessa expressão para definir os indígenas que se opõem aos indígenas "puros" do passado. Oliveira Filho (1999b) problematizou esse termo como sinônimo de "ex-índios".

Para Portela (2006), a história dos Karajá de Aruanã mostrou que sua situação de marginalização sociocultural foi historicamente consolidada por meio do estigma de "aculturação", resultando na redução da importância da identidade étnica desse povo. Isto não aconteceu somente com esse grupo específico, mas com quase todos os povos indígenas brasileiros, uma vez que ainda persistem imagens simplificadoras, estereotipadas e estigmatizadas das e dos indígenas na sociedade brasileira contemporânea, as quais foram e continuam se incorporando à nossa cultura.

Entre essas imagens, encontram-se as de: "índios selvagens", "índios de verdade", "índios atrasados", "índios explorados", "índios guardiões da natureza", "índios aculturados", "índios misturados", "índios mansos", "índios de índole pacífica", "índios assistidos", "índios miseráveis e dignos de pena", "índios manipulados", "índios privilegiados" (PORTELA, 2006), "índios isolados", "índios contatados", "índios integrados", "silvícolas", "índios primitivos", "índios miscigenados", "bárbaros", "índios genéricos" (AMORIM, 2003).

Para Amorim (2003 e 2010), o problema da miscigenação é um dos aspectos ideológicos que atravessa a concepção da população não indígena em relação aos indígenas atuais, decorrente da dificuldade de entendê-los. Assim, o autor afirma que a mistura de raças no Brasil, defendida como "orgulho nacional", para os povos indígenas, 
especialmente os "ressurgidos", é um drama, uma vez que

[...] isso implica em serem reconhecidos como índios somente por seus semelhantes ou em eventos públicos (durante 0 processo de ressurgência) ou organizacionais, adotando estrategicamente as representatividades dos grupos nos quais se apóiam ou dos quais descendem, fato configurado pelo processo de busca da construção identitária dos povos pela busca de reconhecimento consubstanciado nos momentos seguintes (AMORIM, 2003, p. 26).

Para Prezia e Hoornaert (2000), os povos indígenas "emergentes" perderam sua língua e parte de sua cultura tradicional. Entretanto, segundo Amorim (2003), eles não se distanciaram de suas práticas ancestrais e de seus descendentes por desejo próprio, ao contrário,

[...] lutaram contra todos os tipos de violações e sobreviveram a momentos de muitas injustiças, mortes, assassinatos, humilhações, além das perdas irrecuperáveis, tanto físicas como culturais, ecológicas, religiosas, sociais e territoriais (AMORIM, 2003, p. 4445).

Prezia e Hoornaert (2000, p. 89, destaques no original) definiram, a partir dos novos conceitos da antropologia, "ser indígena" como "[...] considerar-se diferente da sociedade nacional, por apresentar uma ligação histórica com as sociedades pré-colombianas, sendo descendente dos primeiros ocupantes deste continente" 6 . Segundo esses autores (2000), "ser indígena" não é resultado de aspectos biológicos, de raça, mas uma questão étnica, cultural, uma vez que os povos indígenas tiveram suas identidades espoliadas

[...] devido às políticas de miscigenação forçada, à imposição da Língua Portuguesa e da religião católica, à adoção de costumes e técnicas da sociedade nacional, além da invasão de suas terras, áreas de caça, pesca e atividade agrícola fundamentais para a manutenção de sua cultura (PREZIA e HOORNAERT, 2000, p. 90).

Neste sentido, a miscigenação, que de acordo com Prezia e Hoornaert (2000) foi um dos fatores da perda cultural, incentivada pelo

\footnotetext{
${ }^{6}$ O termo "descendente" é questionado por Arruti (1997), Oliveira (1998) e Amorim (2003).
} 
governo colonial e servindo de pretexto para o roubo das terras indígenas, para Amorim (2003, p. 25), foi também utilizada como forma de sobrevivência dos povos indígenas, tornando na atualidade "[...] única via de continuidade e representatividade ancestral".

Pela análise de Amorim (2003), entendemos que a miscigenação foi uma das estratégias utilizadas pelos e pelas indígenas puruborá para sobreviver. Em função dessa miscigenação, ocorreram perdas culturais significativas, uma vez que foram forçados a adotar outra cultura, outros costumes e outra língua, inclusive forçados a se casarem com seringalistas oriundos do Nordeste que foram recrutados para trabalhar na região.

É importante destacar a discordância de Oliveira (1998) quanto à afirmação de que houve perda cultural nos processos de miscigenação, pois, embora a imposição da cultura não indígena aos povos indígenas tenha acarretado a perda de muitas características específicas desses grupos, também houve mudanças culturais positivas, por meio das apropriações que esses povos fizeram, como, por exemplo, da escola.

Amorim (2010) afirma que as comunidades indígenas que se dispersaram na região ribeirinha do médio e baixo São Francisco vivem como não indígenas nas cabeceiras das cidades vizinhas e nas periferias dos postos indígenas oficiais, em busca de sobrevivência e/ou melhoria de vida, especialmente por fazerem parte da dinâmica de desterritorialização histórica:

Subsistindo como camponeses, esses grupos vivem
executando trabalhos eventuais nestes municípios, no
campo como meeiros, isto é, plantando em terreno
alheio e dividindo pela metade a safra, ou finalmente
prestando serviços temporários em terras arrendadas
nos currais, canaviais, nos municípios ou no campo,
durante as colheitas de feijão, milho, mandioca, arroz,
entre outros produtos agrícolas (AMORIM, 2010, p. 59).

No caso do povo Puruborá, após serem expulsos de seu território tradicional, também se dispersaram pelo Vale do Guaporé e outros municípios (zona urbana e rural) do estado de Rondônia, obtendo sua sobrevivência do trabalho por diárias e/ou empreitas para os fazendeiros locais, cultivando roças de subsistência, vendendo leite para os laticínios da região, pescando e caçando na terra de que eles detêm a 
posse, trabalhando de forma assalariada nos municípios em que residem e/ou próximos, frequentemente sendo alvos de episódios de preconceitos, constrangimentos e discriminação.

E foi no momento em que se processava a extinção dos povos indígenas, sustentada pelas imagens simplificadoras, estereotipadas e estigmatizadas que se produziram acerca deles que, segundo Arruti (1997), por volta da década de 1870 no Nordeste, alguns grupos indígenas da região "ressurgiram", entre eles o Pankararu.

Segundo Portela (2006), essa mudança do pressuposto da extinção das sociedades indígenas só deixou de ser tônica central pelos movimentos sociais que as próprias e os próprios indígenas organizaram. Ou seja, para a autora, as e os indígenas são considerados como agentes desse processo, buscando romper com a visão desses povos como vítimas passivas do processo avassalador.

Corroborando esta ideia, Amorim (2003) destaca que os povos indígenas têm se mostrado ativos no

[...] processo de reconstrução cultural e identitário, na busca de reconhecimento étnico oficial, delimitando e demarcando seus territórios tradicionais, recuperandoos para a prática de suas atividades de sobrevivência e rituais ancestrais (AMORIM, 2003, p. 32).

O movimento indígena tem se fortalecido e constitui-se como estratégia de resistência, e está contribuindo com o reaparecimento, nos cenários sociopolíticos, das identidades indígenas consideradas extintas ou desaparecidas (AMORIM, 2003 e 2010). O termo "ressurgido" significa, neste contexto, o resgate da história desses povos, da intenção de retomar suas origens e suas culturas, do reconhecimento e da reafirmação de suas identidades, as quais se contrapõem aos padrões de reconhecimento étnico do indigenismo oficial, da reafirmação de suas autoimagens e das demarcações de seus territórios. (AMORIM, 2003 e 2010).

Segundo Amorim (2003 e 2010), ressurgir é "sair do anonimato", "dar-se a conhecer", "apresentar-se", "levantar-se" como indígenas depois de meses e/ou anos sem assim o fazerem ao órgão oficial e à sociedade local. Esse autor (2003) afirmou que, para as e os indígenas, "ressurgir" significa o reconhecimento e reordenação de suas memórias, 
suas trajetórias e seus espaços étnicos.

Ainda no dizer de Amorim, após uma reunião entre o Conselho Indigenista Missionário (Cimi) e um grupo de antropólogos da Universidade Federal do Rio de Janeiro (UFRJ):

[...] ao analisar essa proposta, chegaram à conclusão de que o termo emergente faria uma relação direta com os grupos sociais economicamente "bem sucedidos" no Brasil, cujos sujeitos se "distanciariam das questões e lutas populares", enquanto que o de ressurgido - a partir mesmo de seu significado semântico e representativo - se adequava a situações de emergência étnica no sentido mesmo de ressurgir: "Tornar a surgir; reaparecer. Tornar à vida, reviver, ressuscitar, manifestar-se novamente, tornar a manifestar-se" (AMORIM, 2003, p. 41, destaques no original).

Entretanto, segundo o autor (2003), o termo "ressurgidos" também está vulnerável a críticas, uma vez que se trata de um termo oriundo de um órgão fundamentado nos princípios da Igreja Católica, o Cimi, respaldado pela Conferência Nacional dos Bispos do Brasil (CNBB) e, por isso,

[...] poderá estar sujeito à ideologia de uma chamada 'volta', a um 'puritanismo étnico', o qual pode sugerir [...] uma 'volta' de valores pré-coloniais indígenas, o que seria 'uma utopia irrealizável', no que se refere às perdas de espaços (território/cultura) e distância temporal desses povos as suas origens (AMORIM, 2003, p. 41-42, destaques no original).

Frequentemente também tem sido utilizado o termo "emergentes" para se referir aos indígenas nessa situação. Oliveira Filho (1999b, p. 148) conceituou "emergência étnica" como o processo "[...] pelo qual populações que anteriormente camuflavam sua identidade indígena hoje a colocam no centro de um processo de reorganização social e de reelaboração cultural".

Para Oliveira (1998), é incômoda a caracterização de "índios emergentes". Segundo ele, esse termo,

por um lado, sugere associações de natureza física e mecânica quanto ao estudo da dinâmica dos corpos, o 
que pode trazer pressupostos e expectativas distorcidos quando aplicada ao domínio dos fenômenos humanos. Como imagem literária, ao contrário, reporta-se a uma aparição imprevista, enfatizando o fator surpresa. Por sua ambigüidade, pode ser suscetível de usos variados sem, no entanto, contribuir para o entendimento de aspectos relevantes do fenômeno que designa (OLIVEIRA, 1998, p. 62-63).

Entretanto, de acordo com Amorim (2003), a "emergência" está acontecendo desde meados do século $X X$, sendo uma estratégia política de luta e (re)conquista que ocorre por meio do ato de assumir-se publicamente como indígena. Assim,

[...] a emergência os predispõe politicamente de frente com o Estado, com a FUNAI, com os grupos do poder que os excluem há séculos. A emergência, nesse sentido, "legitima suas lutas" e enfrentamentos, enquanto o ressurgimento os coloca no caminho de seus ancestrais, mas pelas vias do Direito, da Democracia, e não de forma violenta (AMORIM, 2003, p. 43, destaque no original).

Para o autor, portanto, não há separação entre emergência e ressurgimento. E Araújo (2011) esclarece que o termo "ressurgidos" foi atribuído pelo Cimi, enquanto "emergentes" é o termo utilizado pelos antropólogos especializados na temática indígena.

Amorim (2003) afirmou que os povos participantes do / Encontro Nacional dos Povos Indígenas em Luta pelo Reconhecimento Étnico e Territorial, ocorrido em 2003 na cidade de Olinda(PE), optaram pelo termo "resistentes":

Nos debates, os povos indígenas que participaram desse Primeiro Encontro chegaram à conclusão de que devem ser reconhecidos por sua história de resistência, e não mais por uma suposta ressurgência ou emergência étnica, como vinham sendo reconhecidos os índios do Nordeste ou aqueles que foram destituídos de seus territórios e práticas culturais, religiosas, sociais, mas que, apesar de tudo, reapareceram no cenário político do indigenismo institucional, em busca de seus direitos (AMORIM, 2010, p. 51).

O autor relatou o processo de resistência indígena dos povos nordestinos Tumbalalá, Kalankó, Karuazu, Catókinn e Koiupanká, os 
quais eram desconhecidos na região, não figuravam como indígenas no mapa desses povos no Brasil, mas que ressurgiram do anonimato após décadas ou séculos. Segundo o autor, eles

[...] foram arrebatados de suas línguas originais, costumes, traços físicos, culturais e sociais, razões pelas quais foram se apropriando e assimilando elementos de outras culturas, passando, por exemplo, a somente falar o português. Inevitavelmente, foram levados a se relacionar nos padrões da sociedade dominante e seus costumes mantendo, porém, o resgate das tradições e rituais de seus ancestrais, cuja história atual se confunde e se mescla com a dos seus conquistadores europeus (AMORIM, 2003, p. 47).

Esses povos foram obrigados a se apropriarem de elementos tradicionais indígenas e a reelaborarem formas de representações étnicas que respaldem uma identidade diferenciada, modelada em signos tradicionais indígenas visíveis. Ou seja, utilizam sempre um objeto que represente, indique e/ou afirme sua identidade indígena ao se apresentarem. Dessa forma, necessitam dar visibilidade às suas trajetórias étnicas e resistências como "índios", provando sua identidade por meio de "[...] signos que identificam o índio estereotipado: um arco e flecha, uma borduna, um cocar, um colar ou, então, pintando-se, construindo e reconstruindo uma identidade visual que por séculos 'foi abandonada"' (AMORIM, 2003, p. 132, destaque no original).

Amorim (2003, p. 15, destaque no original) mencionou, ainda, que, com exceção dos Kalankó, os povos Tumbalalá, Karuazu, Catókinn e Koiupanká não tinham "[...] um etnônimo próprio, nem formas de representações que os identificassem como índio 'tal', da aldeia 'tal'. Isso foi construído durante o processo, que exigia deles apresentação visível e representatividade étnica". Assim, para este autor, o processo de ressurgimento indígena requer um grande esforço dos povos nessa situação com vistas a resgatar suas ancestrais origens e suas histórias de vida, assumindo-se como indígenas diante de si mesmos e da sociedade majoritária e, também, empreendendo uma longa trajetória em busca do reconhecimento formal de sua identidade e, por isso, a partir desse momento é preciso

[...] dar continuidade às relações interétnicas 
estabelecidas e manter diferentes vínculos com seus semelhantes, com a sociedade local, com o movimento indígena, além de interagir com o mundo político (as demandas de terra para trabalhar, saúde e educação diferenciada - principais bandeiras de luta dos povos indígenas atuais) e seu universo social [...] (AMORIM, 2003, p. 27).

Além disto, o ressurgimento é considerado dentro do movimento indígena uma nova forma de inserção desses povos não reconhecidos como tais pelo indigenismo oficial, uma vez que ele "[...] insiste em manter os povos ressurgidos como uma população sem direito e suas realidades, enclausuradas em práticas políticas diferenciadas, que precisam 'ressurgir' comprovando uma etnia a partir de parâmetros das instituições oficiais que lhes são exteriores" (AMORIM, 2003, p. 33-34, destaque no original), o que pode levar os povos indígenas a transitar por caminhos desconhecidos em busca de afirmação e reconhecimento identitário.

Portela (2006) afirma que os Karujá de Aruanã "[...] não ressurgiram, nem emergiram, e sim, resistiram historicamente a um processo de invisibilização social e de silenciamentos discursivos" (PORTELA, 2006, p. 212). Segundo a autora, as fronteiras étnicas desse grupo indígena estiveram sempre mantidas, e negar a ideia de ressurgimento possibilita dar visibilidade à situação histórica desse povo, evidenciando que a identidade indígena e/ou o sentimento de pertencimento étnico sempre estiveram presentes, portanto, não é possível afirmar que "nasceram" na década de 1990.

Amorim (2010) afirmou que a emergência étnica, ressurgência ou resistência indígena é concebida e encarada como legítima por antropólogos, entidades de apoio à causa indígena e pelo movimento indígena, concluindo que, do ponto de vista etimológico, esses termos

[...] conotam a mesma idéia, daí que, nesse sentido, antropólogos, historiadores, missionários, indigenistas fizeram uso desses termos para designar os povos indígenas submetidos "às artimanhas do capitalismo" e ao indigenismo oficial. As categorias de emergentes e ressurgidos passaram a "substituir" as de "povos integrados" ou "aculturados", entre outras utilizadas antes do reaparecimento público dos Kalankó, em 1998. Enquanto a de povos integrados e derivações 
dessa foram suprimidas em 1988, pela Constituição Federal atual, em função da necessidade de agrupar teoricamente esses povos no contexto político, de forma a situá-los no processo de democratização social brasileira (AMORIM, 2010, p. 73 - Destaques no original).

Diante do exposto, defendemos que o povo Puruborá pode ser denominado como "ressurgido" no sentido exposto por Amorim (2003 e 2010), uma vez que o próprio grupo assim se denomina, supostamente por influência do Conselho Indigenista Missionário de Rondônia (CimiRO), conforme registra Catheu (2002).

Porém, designar as e os Puruborá apenas como "ressurgidos" significaria ignorar a histórica resistência desse povo que durante décadas omitiu sua identidade como estratégia de sobrevivência, inicialmente diante dos constantes massacres e, mais tarde, como forma de enfrentar os preconceitos. Por isso também os denominamos como resistentes, pois no movimento de reagrupamento, organização e luta pelo reconhecimento se evidencia que a identidade indígena puruborá sempre esteve presente, mesmo que proibida, tornando-se elemento fundamental na luta para acessar seus direitos constitucionais, conforme os elementos da história desse povo apresentados na próxima seção.

\section{Primeiras aproximações: um pouco da história do povo Puruborá}

Segundo os registros históricos, as e os Puruborá foram contatados por volta de 1909, pelo marechal Cândido Rondon, que as e os deixou na região do Rio Manoel Correia, afluente do Rio São Miguel (BARBOZA, 2012; BIAZATTI, OLIVEIRA e BRITO, 2013; CASSIMIRO e BARBOZA, 2012; CATHEU, 2002; GALÚCIO, 2005; LEONEL, 1995; OLIVEIRA, BRITO e BIAZATTI, 2012).

Existe divergência em relação ao ano de contato com as e os Puruborá. Galúcio (2005) e Catheu (2002) afirmam que Rondon contatou esse povo em 1919. Um dos projetos desenvolvidos pela professora indígena Gisele, em 2012, que resultou no trabalho intitulado História tradicional do povo Puruborá: Narrativas na escola indígena Ywará 
Puruborá, registrou que o ano do contato foi 1909, portanto dois argumentos corroboram a data de 1909. O primeiro deles refere-se ao fato de este ser o ano mencionado pelos e pelas Puruborá. O segundo argumento é fornecido por Oliveira (2007), que nos informa que a terceira e última etapa da instalação das linhas telegráficas foi iniciada em 1909, quando marechal Rondon veio com a sua comissão. Em 1915, ocorreu a inauguração da linha telegráfica unindo Cuiabá a Santo Antônio do Rio Madeira, ainda pertencentes ao estado de Mato Grosso.

Os e as Puruborá teriam ficado sob os cuidados de José Félix Alves do Nascimento, um encarregado do Serviço de Proteção ao Índio (SPI), na área destinada aos indígenas desse povo, denominada Posto Três de Maio8 (LEONEL, 1995). De acordo com o mesmo relato, Rondon teria feito a demarcação do território em favor do povo Puruborá e outros grupos "arredios", afixando pedaços de madeira no chão (BIAZATTI, OLIVEIRA e BRITO, 2013; CATHEU, 2002).

De acordo com Leonel (1995), após ser abandonado pelo SPI, o encarregado José Felix Alves do Nascimento endividou-se, casou-se com uma índia e aprendeu a língua puruborá. Posteriormente, José Felix foi substituído por Arlindo de Souza Freitas, e esse episódio, segundo Barboza (2012, p. 10), "[...] é narrado como o início do declínio do posto e o acelerador do processo de desagregação dos Puruborá".

Uma comissão do SPI, em 1952, recomendou o arrendamento das terras puruborá aos seus próprios invasores; entres eles, a empresa Massud \& Kalil, junto a qual José Felix havia se endividado, sendo que após um ano os herdeiros dessa empresa "[...] entram em litígio com o SPI, e reivindicam a posse da área por eles invadida e arrendada" (LEONEL, 1995, p. 96).

Houve conflitos entre não indígenas e indígenas, em um dos quais Paulo Aporety, indígena puruborá, foi acusado de estar extraindo seringa nas terras particulares de Juarez Uchoa. No entanto, o SPI propôs que Juarez Uchoa indenizasse Paulo Aporety "[...] pelas

\footnotetext{
${ }^{7}$ Trabalho manuscrito desenvolvido em 2012 como uma ação prática executada na aldeia Aperoi, como requisito avaliativo da disciplina "Estudos na Aldeia V" do curso superior de Licenciatura em Educação Básica Intercultural com o objetivo de revitalizar a história tradicional do povo Puruborá (MONTANHA, 2014).

${ }^{8}$ Há divergência em relação ao nome desse posto indígena. Leonel (1995) o denominou de Três de maio, mas os colaboradores e as colaboradoras Puruborá de um projeto de extensão e nos registros das atas analisadas, apareceu como Posto Dois de Maio.
} 
benfeitorias feitas e que volte o índio à área demarcada", uma vez que o SPI argumentou que "[...] os dados do processo que tem em seu poder mostram que J. Uchoa está fora da área", e, por isso, posteriormente, foi recomendado que o conflito fosse levado à autoridade policial (LEONEL, 1995, p. 96).

No relato foi apresentada a versão do seringalista Juarez Uchoa, o qual declarou que inicialmente trabalhou nas terras indígenas da família "Porety", pagou arrendamento ao funcionário do SPI e posteriormente teria adquirido as benfeitorias indígenas, pagando com mercadorias, mas depois os indígenas se arrependeram do negócio e passaram a dificultar o ingresso dos seringueiros, ocorrendo, assim, trocas de ameaças (LEONEL, 1995).

Desta forma, nos anos pós-contato, o povo Puruborá sofreu as consequências resultantes do encontro entre indígenas e não indígenas, tais como epidemias de sarampo, gripe, catapora, entre outras, que quase dizimaram a população. É importante destacar que a história deste povo não está desconectada da história da criação do território do estado de Rondônia9.

Segundo Teixeira e Fonseca (2003), as doenças e epidemias já faziam parte do cotidiano da população guaporeana10, sendo que "a morte era uma possibilidade sempre muito real e próxima em toda região [...]" (TEIXEIRA e FONSECA, 2003, p. 77). Estes autores citam as doenças e epidemias que assolavam a região: "A Malária (malárias), máculos ou corruções, febres catarrais, pneumonias, diarréias sanguinolentas, tuberculose, febre amarela, tifo e cólera [...]" (TEIXEIRA e FONSECA, 2003, p. 77), bem como as epidemias da bexiga, sarampo e verminoses.

Além das epidemias, os dois ciclos da borracha contribuíram para a morte de outros membros do povo Puruborá, os quais, segundo Catheu (2002), foram recrutados para trabalhar como extratores, ampliando a situação precária de sua saúde e acentuando o número de mortes em decorrência do contato e da precarização do trabalho.

\footnotetext{
${ }^{9}$ E não somente a história do povo Puruborá, mas dos demais grupos indígenas de Rondônia. Para maiores informações sobre o processo de ocupação do estado e o impacto sobre as sociedades indígenas, recomendamos a leitura dos autores Teixeira e Fonseca (2003) e Oliveira (2007), e a sistematização feita por Santos (2014) no primeiro capítulo de sua dissertação.

${ }^{10}$ População moradora do Vale do Guaporé, do qual o atual município de Seringueiras faz parte.
} 
Estudiosos da história de Rondônia, entre eles Oliveira (2007), relataram que durante o primeiro ciclo da borracha (1877 a 1910) ocorreu a grande demanda da extração do látex na Amazônia para abastecimento das indústrias estrangeiras, o que tornou a região amazônica um polo atrativo, principalmente para os nordestinos, pois "[...] não tinham nenhuma perspectiva de vencer a seca que assolava o sertão entre 1877 e 1879" (OLIVEIRA, 2007, p. 37).

Teixeira e Fonseca (2003) afirmam que durante o primeiro ciclo da borracha ocorreu o avanço em direção aos territórios indígenas, principalmente em busca de mão de obra para trabalhar na extração do látex. Assim:

\begin{abstract}
A força de trabalho indígena continuou, durante esse período, a participar significativamente da economia amazônica, seja no extrativismo, na atividade de transporte ou na lavoura. Os indígenas amansados foram entregues às diretorias de índios, cujos dirigentes exploravam cruelmente o trabalho desse elemento, visando dele extrair o maior ganho possível. Eram ainda os nativos vendidos ou trocados dentro da região, havendo também casos de contrabando de indígenas que eram objetos de escambo (TEIXEIRA; FONSECA, 2003, p. 27).
\end{abstract}

De acordo com Oliveira (2007), o primeiro ciclo da borracha possibilitou a instalação das Linhas Telegráficas Estratégicas do Mato Grosso ao Amazonas e a construção da Estrada de Ferro MadeiraMamoré (EFMM), margeando o Rio Madeira.

Entretanto, Teixeira e Fonseca (2003, p. 24) afirmam que "com a queda das exportações da borracha arrefeceu o genocídio". Porém, essa trégua durou pouco tempo, pois com a Segunda Guerra Mundial, o interesse norte-americano em reativar a produção da borracha cresceu novamente, aumentando a intensidade da guerra contra as populações indígenas da região, por meio "[...] da ampliação da conquista sobre as áreas ainda de domínio indígena, com a abertura de novos seringais, que iniciavam por espalhar-se pelos rios mais remotos da Amazônia [...]" (TEIXEIRA e FONSECA, 2003, p. 122-123) e "[...] da intensificação do combate ao indígena, tanto para expulsá-lo das mediações das novas áreas de extrativismo, como para escravizá-lo ao seringal" (TEIXEIRA e FONSECA, 2003, p. 123). 
Conforme explicitam as palavras de Teixeira e Fonseca (2003):

Durante a $2^{\mathrm{a}}$ Guerra, a intensa migração nordestina destinada a satisfazer o novo crescimento da demanda da borracha, para o mercado norte-americano, intensificou a ocupação dos territórios indígenas do Madeira/Mamoré/Guaporé. Nas décadas seguintes a descoberta de metais e de pedras preciosas, de cassiterita e a abertura da BR-364 fez com que os territórios indígenas fossem ocupados por grileiros e posseiros que promoviam massacres para afugentar os nativos dessas áreas (TEIXEIRA e FONSECA, 2003, p. 27).

O resgate realizado pela indígena Gisele Montanha'11 (2014), em seu trabalho de conclusão do curso de Licenciatura em Educação Básica Intercultural, assegura que seu povo sofreu a opressão nos seringais do Rio Manoel Correia, sendo forçado pelo SPI a adotar outra cultura, tradições, costumes, mitos e língua, sendo acometido por diversas doenças e obrigado a conviver com os seringalistas oriundos da região nordeste, que forçaram a mestiçagem.

Como mencionamos anteriormente, a miscigenação ou mestiçagem contribuiu para que algumas características específicas dos povos indígenas deixassem de existir (PREZIA e HOORNAERT, 2000), uma vez que esses povos, mediante o confronto com os e as não indígenas, foram expropriados de suas línguas, costumes, traços físicos, culturais e sociais e obrigados a se apropriar e assimilar elementos das outras culturas para a sobrevivência (AMORIM, 2003).

Assim, de acordo com Prezia e Hoornaert (2000), o roubo das terras indígenas foi justificado pela miscigenação. Neste sentido, Arruti (1997) afirmou que o diagnóstico de "mistura" dos povos indígenas no nordeste foi a causa da extinção dos aldeamentos e a repartição em lotes que deveriam ser distribuídos entre os antigos aldeados e entre as e os "nacionais".

No caso de Rondônia, especialmente do povo Puruborá, essa

\footnotetext{
${ }^{11}$ A professora Gisele Montanha era a professora da escola do povo Puruborá durante a realização da pesquisa. Doravante, quando utilizarmos o trabalho de conclusão de curso (TCC) de Licenciatura em Educação Básica Intercultural que Gisele concluiu em 2014, faremos menção a ela como Montanha (2014), em atenção às normas da Associação Brasileira de Normas Técnicas (ABNT). Porém, quando utilizarmos os dados obtidos e produzidos durante o trabalho de campo, utilizaremos o primeiro nome da participante.
} 
também foi a causa para o desaldeamento e posterior dispersão deste povo, conforme registro localizado em trabalho coordenado pela professora Gisele Montanha, intitulado História tradicional do povo Puruborá: Narrativas na escola indígena Ywará Puruborá, produzido a partir dos relatos das e dos puruborá no qual duas integrantes da comunidade relataram: "Nós Puruborá não fomos só prejudicado, nosso povo foi quase todo dizimado e todos nós desaldeado"12 (MONTANHA, 2014, p. 4).

Devido às epidemias e à forte exploração do trabalho indígena, José Félix do Nascimento organizava festas e promovia a adoção de crianças órfãs por parte dos seringueiros, na grande maioria nordestinos. Os seringueiros foram incentivados a ocupar área tradicional da reserva por esse mesmo encarregado da proteção das terras (CATHEU, 2002; OLIVEIRA, BRITO e BIAZATTI, 2012).

Segundo Barboza (2012, p. 11), as e os puruborá foram alvos de três expulsões, sendo que a primeira se deu "[...] entre a década de 1910 até 1940, quando os órgãos oficiais e seus dirigentes estimularam a invasão das terras pela companhia Massud e Kalil e, dos vários seringueiros". A segunda expulsão ocorreu durante a delimitação da Reserva Biológica (Rebio) do Guaporé em 1982, pois esta abrange as áreas de Limoeiro, lugar onde habitavam e ainda habitam vários puruborá (BARBOZA, 2012; CASSIMIRO e BARBOZA, 2012; LEONEL, 1995).

A terceira expulsão aconteceu com o processo de delimitação da terra indígena Uru Eu Wau Wau (BARBOZA, 2012; MONTANHA, 2014), ocorrida em 1990, quando as e os puruborá que moravam no seu território tradicional foram expulsos pela Funai e este episódio de expulsão foi relatado na ata $\mathrm{da} 3^{\mathrm{a}}$ assembleia do povo Puruborá, ocorrida em dezembro de 2003. As referidas atas são registros produzidos nos encontros anuais que contêm a relação das pessoas presentes, os temas abordados e também as reivindicações e os encaminhamentos. De acordo com o registro, o marido de dona Emília tentou argumentar que ele era seringueiro e sua esposa indígena, mas

\footnotetext{
${ }^{12}$ Manteremos a escrita original dos documentos recolhidos em campo, ressaltando que o objetivo dessa escolha é ser fiel ao registro escrito do outro e da outra, mesmo que apresente limites se comparado com a norma oficial de escrita.
} 
não foram ouvidos.

Sobre esse episódio, ainda julgamos importante destacar que o território do estado de Rondônia, historicamente, foi espaço de perambulação de vários grupos indígenas, sendo que em várias situações aconteceram disputas pela superposição das terras. Ou seja, um povo indígena afirmava que um determinado território era dele, porém, outro povo indígena fazia a mesma afirmação. De acordo com Leonel (1995), a análise da demarcação da Terra Indígena Uru Eu Wau Wau deve considerar aspectos políticos, históricos e econômicos.

Após as expulsões, por não terem para onde ir, as e os remanescentes se dispersaram por várias cidades de Rondônia (diáspora puruborá): Costa Marques, Seringueiras, São Francisco, São Miguel, JiParaná, Ariquemes, Porto Velho e Guajará-Mirim; e ainda para fora do estado de Rondônia, sendo que dona Emília, matriarca do povo Puruborá, e sua família foram morar às margens da BR 429. Ou seja, expropriados de sua terra, grande parte do povo Puruborá teve que se fixar em cidades próximas e trabalhar no espaço não indígena para garantir a sobrevivência (BARBOZA, 2012; BIAZATTI, OLIVEIRA e BRITO, 2013; CASSIMIRO e BARBOZA, 2012; CATHEU, 2002; MONTANHA e BARBOZA, 2013; MONTANHA, 2014; OLIVEIRA, BRITO e BIAZATTI, 2012).

Sobre esse episódio, Hozana mencionou:

Porque essa culpa toda, eu falo assim: "Eu culpo a Funai". Porque quando a Funai demarcou a terra dos Uru Eu, nóis já vivia lá. No momento que meu pai falou que minha mãe era índia, era pra alguém ter ouvido ele e buscar as história. Não deixar acontecer isso aí. E na época ninguém sabia a quem ia buscar, porque, que nem te falei, se, naquela época, se eu soubesse o que eu sei hoje, isso não tava assim. [...] E a deles já tá demarcada. Nós saímos para eles entrar. Sendo que era nossa, né? [...] Porque quando meu pai falou assim: "Minha mulher é índia"; eles devia ter feito isso, né? "Então nós vamos buscar, já que tem uma índia aqui, vamos buscar da donde que ela veio ou se ela nasceu aqui". Não, né? "Se ela é daqui, vamos demarcar a terra pra ela também, não tirar" (Entrevista Hozana, 04/09/2014).

Nesse terceiro processo de expulsão, na década de 1990, o povo Puruborá teve sua identidade negada pela Funai, que era e é o órgão 
público que deveria protegê-lo e assegurar a integridade do território habitado originariamente pelos seus ancestrais. E ainda, esse povo passou e tem passado por todo tipo de humilhação após a expropriação de sua terra e, buscando resistir, adquiriram, principalmente por meio da venda de gado, terras que originalmente lhes pertenciam ${ }^{13}$ (BARBOZA, 2012; BIAZATTI, OLIVEIRA e BRITO, 2013; OLIVEIRA, BRITO e BIAZATTI, 2012).

Pela aquisição das terras no município de Seringueiras, por parte de dona Emília, alguns integrantes do grupo começaram a se reagrupar, nomeando esta área particular de Aldeia Aperoi, organizando-se em torno dela em busca de seus direitos, evidenciando a resistência desse povo.

De acordo com dados do Conselho de Missões entre Povos Indígenas (Comin), existem mais de 400 pessoas dispersas pelos estados de Rondônia e Mato Grosso que se identificam e são identificadas como puruborá, as quais sonham com o retorno e a conquista de sua terra ancestral, sendo que a demarcação do seu território está estreitamente ligada à revitalização da cultura e à afirmação da identidade deste povo. (COMIN, 2007).

No trabalho História tradicional do povo Puruborá: Narrativas na escola indígena Ywará Puruborá, a professora Gisele registrou:

O povo Puruborá é um povo que luta pelos seus direitos, mesmo tendo sua identidade indígena negada várias vezes, sofrendo os mais variados preconceitos por não terem os traços físicos que a comunidade nacional diz que os indígenas têm, nunca desistiram de lutar pelos seus direitos (apud MONTANHA, 2012, p. 1).

$\mathrm{Na}$ continuidade deste texto, apresentaremos elementos que têm caracterizado a luta do povo Puruborá após o ressurgimento.

\subsection{O "ressurgir" do povo Puruborá: a luta pela demarcação do território e pela revitalização da cultura e da identidade indígena}

Os estudos sobre os povos "ressurgidos" foram mais

\footnotetext{
${ }^{13}$ Esse episódio é relatado na ata da $3^{\mathrm{a}}$ assembleia do povo em 2003.
} 
intensificados no final do século XX, sendo que, de acordo com Barboza (2012, p. 4), "[...] esse cenário é completamente inexplorado se falarmos em povos indígenas ressurgidos na Amazônia [...]".

Montanha (2014, p. 30) afirma que o nome puruborá "[...] significa aquele que se transforma em onça". Essa força se expressa na história do povo que vem resistindo historicamente a "processos de invisibilização social" e "silenciamento discursivo", mantendo sua identidade, mesmo quando proibida.

Assim, conforme relato de uma das integrantes do povo:

Nós povos indígenas sofremos muito, pois os
preconceitos são demais só porque alguns não são
parecidos e nem tem traços físicos de índios; mas isso
está acontecendo hoje em pleno século XXI porque as
escolas e a mídia retratam um índio "autêntico", "puro",
verdadeiro e isso não pode acontecer. E nós que
sofremos com esses tipos de preconceitos baratos
temos mais é que ir no ministério Público Federal e
denunciar (Projeto História tradicional do povo
Puruborá: Narrativas na escola indígena Ywará
Puruborá, 2012, destaques no original).

Albuquerque (2012) esclarece que é muito trabalhoso para as e os indígenas precisarem provar e ter reconhecida, pública e oficialmente, a sua identidade, especialmente quando vivem por longo tempo junto às comunidades não indígenas, pois já perderam as características atribuídas nacionalmente aos povos indígenas.

Em relação à miscigenação, o povo Puruborá é um grupo étnico misturado com negros, "brancos", outros povos indígenas, bolivianos e quilombolas (BARBOZA, 2012). Essa miscigenação, que não é bem-vista pelos e pelas não indígenas, muitas vezes também não é bem-vista pelas próprias populações indígenas do estado de Rondônia. Em entrevista, o professor Deivid mencionou que o reconhecimento do seu povo tem sido uma grande meta a conquistar, uma vez que "[...] quando ressurge um povo, ainda mais nós povo Puruborá... porque não temos muita característica do próprio índio puro, né? [...] existe uma rejeição dos outros parentes ${ }^{14}$ indígenas também" (Entrevista Deivid, $11 / 09 / 2014)$.

${ }^{14} \mathrm{E}$ a forma que os Puruborá utilizam para se referir aos demais indígenas de outras etnias. 
Além disto, durante o trabalho de campo ${ }^{15}$, Gisele relatou um episódio de discriminação sofrido na Fundação Universidade Federal de Roraima (Unir), enquanto estava fazendo uma das disciplinas do curso de licenciatura em educação básica intercultural. Segundo ela, enquanto estava fazendo um trabalho do curso, uma das professoras pediu que os alunos e as alunas escrevessem uma história na língua materna para acrescentar ao trabalho. Gisele disse que não sabia a língua materna e por isso não poderia fazer. A professora solicitou que escrevesse na língua portuguesa, mas Gisele se recusou, alegando que não era justo toda a turma fazer em suas línguas maternas e ela não. De acordo com Gisele, a professora insistia, pois seu trabalho tinha ficado muito bom. Nesse momento, um colega, irritado com a situação, disse à professora que Gisele era amarela, não era indígena, por isso não sabia falar em sua língua materna e não sabia o que Gisele estava fazendo no meio deles (DIÁRIO DE CAMPO, 04/09/2014).

Gisele relatou que começou a chorar de ódio, foi para o banheiro e chorou muito. Ligou para sua casa, Aldeia Aperoi, chorando, contando a situação. De acordo com ela, seu pai mandou-a voltar para casa, dizendo que ela não precisava ser humilhada. Ligou para sua mãe, que participava de um evento em Brasília, que, ao contrário, insistiu para que ela não fosse embora, dizendo: "Imagina se todas as vezes que as pessoas disserem que você não é indígena, você chorar" (DIÁRIO DE CAMPO, 04/09/2014).

Segundo Gisele, o episódio aconteceu no sábado. Na segundafeira seguinte, ela procurou o Ministério Público. No mesmo dia, mencionou que o colega se retratou publicamente, pedindo perdão e dizendo que ela era um orgulho, pois fisicamente não parecia indígena, mas orgulhava-se de sua identidade indígena, que poderia ser ocultada se ela quisesse (DIÁRIO DE CAMPO, 04/09/2014).

Estes eventos comprovam que as e os indígenas do povo Puruborá fazem parte de uma comunidade maior (comunidade indígena) e eles se agrupam para lutar pelas causas comuns como, por exemplo, a garantia dos direitos à terra, à educação escolar diferenciada e à saúde. Entretanto, ao mesmo tempo, este povo também é excluído dentro da

\footnotetext{
${ }^{15} \mathrm{O}$ trabalho de campo aconteceu entre os dias 18 de agosto e 18 de setembro de 2014 e, posteriormente, entre os dias 9 de fevereiro e 16 de fevereiro de 2015.
} 
comunidade indígena de Rondônia, já que a imagem indígena divulgada e propagada também envolve a comunidade indígena e, por isso, para se manter indígena, alguns e algumas acreditam que não podem ter sido "misturados".

Isto acontece também em relação à visão dos fazendeiros da região sobre o povo Puruborá. Para eles, esse povo não é indígena, identificando-se desta forma para conseguirem terra, o que tem ocasionado ameaças às e aos puruborá, especialmente à cacique Hozana, como será melhor explicitado posteriormente. Assim, recorremos às palavras de Sawaia (2001, p. 22), quando afirma que "identidade esconde negociações de sentido, choques de interesse, processos de diferenciação e hierarquização das diferenças, configurando-se como estratégia sutil de regulação das relações de poder [...]".

A proibição de ser indígena imposta às e aos puruborá já foi utilizada pelo próprio povo como forma de sobrevivência diante da sociedade. Em entrevista, a cacique Hozana relatou que desde criança ela sabia que era indígena, porque sua mãe e seu pai lhe falavam e que fez o mesmo com seu filho e suas filhas. Entretanto, no seu caso, não podia assumir publicamente que era indígena, pois sofria perseguições:

[...] minha mãe, ela contava assim, que a gente não podia falar que era índio, porque eles matavam. A gente já nasceu sabendo dessas coisas, né? A gente sabia que era índio, mas não podia dizer. Aí do momento que a gente passou a saber que podia dizer que era índio, aí pronto, minha filha, aí eu fui buscar meus direitos, já que é direito, tá na Constituição, né? E a gente vai buscar. Que eu falo assim: "eu não quero nada do que é de ninguém, eu só quero o que é meu de direito" (Entrevista Hozana, 04/09/2014).

O relato acima remete à ideia da identidade como categoria política e estratégia nas relações de poder (CIAMPA, 2002 e 2004; MAHEIRIE, 2002; SAWAIA, 1999, 2001); e como uma questão semifictícia e seminecessária (SANTOS, 2010). Além disto, o momento vivido pelos povos indígenas, inclusive o povo Puruborá, é de contextos favoráveis para as suas "identificações", considerando-se a garantia de direitos expressa na legislação brasileira e nas políticas públicas implementadas 
nos governos do Partido dos Trabalhadores (PT) que, embora limitadas, vêm tentando implementar medidas de respeito e atendimento aos direitos dos povos indígenas, como, por exemplo, as ações afirmativas de acesso ao ensino superior e a criação de cursos específicos de formação de professores indígenas.

O ressurgir do povo Puruborá aconteceu no final da década de 1990 e início de 2000 (BARBOZA, 2012). De acordo com informações da Articulação Nacional de Educação do Cimi (CIMI-ANE, 2004), esse povo foi oficialmente reconhecido pela Funai a partir de maio de 2003.

Montanha (2014) relata que

[...] o povo Puruborá ressurgiu para reafirmar sua existência e continuidade. Esse povo passou por momentos particulares: seu auto-reconhecimento e aceitação de sua identidade como indígenas, sua apresentação como indígenas para a sociedade local, regional e para a FUNAI, e, finalmente sua inserção social em diversas instituições nacionais, internacionais e frente a outros povos. Um fator muito relevante para o ressurgimento foi o fato das pessoas pertencentes à etnia se reconhecerem e afirmarem como indígenas, tendo o desejo de voltar a morar em seu território tradicional (MONTANHA, 2014, p. 16).

Esse ressurgir tem início com a "descoberta", pelo Cimi Rondônia, da existência de famílias do povo Puruborá, conforme relatou Catheu:

O Cimi-Rondônia descobriu a existência de famílias do povo Puruborá no ano passado. Desde então, iniciou uma série de visitas às famílias que vivem no município de Guajará-Mirim. Foi por acaso que foi encontrada a família da dona Emília no município de Seringueiras: a equipe do Cimi estava a caminho do rio São Miguel para encontrar famílias remanescentes do povo Miguelem, quando foi informada que existia na beira da estrada uma família indígena. A equipe parou na casa indicada onde encontrou dona Emília. Viu a sua vontade de voltar para a terra do seu povo e prometeu voltar um dia (CATHEU, 2002, p. 1).

Neste sentido, de acordo com Barboza (2012), foi a partir do auxílio do Cimi Rondônia e do Comin que iniciaram as assembleias anuais do povo Puruborá e a sua organização em busca da demarcação de sua terra. Montanha (2014) confirmou essa informação, reforçando 
que essas entidades, além de cooperarem na organização das assembleias anuais que o povo faz na Aldeia Aperoi, convidando as e os puruborá "[...] que moram nas diferentes cidades do estado de Rondônia, representantes de outras etnias indígenas e representantes de órgãos governamentais que trabalham na causa indígena" (MONTANHA, 2014, p. 18), ajudaram no reconhecimento da identidade indígena do povo perante os órgãos oficiais e outros povos.

Acrescentamos também que esse reconhecimento é resultado das reivindicações do povo Puruborá organizadas durante as assembleias anuais e documentos reivindicatórios produzidos no decorrer delas, uma vez que nos registros das reuniões o povo exige que eles sejam reconhecidos oficialmente e que sua terra seja demarcada, além de outros direitos garantidos legalmente.

A primeira reunião do povo Puruborá aconteceu nos dias 16 a 18 de outubro de 2001, na terra adquirida por dona Emília, hoje nomeada de Aldeia Aperoi. Na ocasião foi registrado como decisão dos presentes nessa reunião: "[...] decidimos recuperar nossa terra para garantir o futuro de nossos filhos e de nossos netos" (ATA DO POVO PURUBORÁ, 200116).

A ata dessa reunião foi lavrada no dia 18 de outubro de 2001 e traz, além da decisão citada acima, um breve registro da história desse povo construído, segundo relatos dos mais antigos que estavam presentes. Foram direcionadas ao presidente da Funai 20 assinaturas e cinco digitais acompanhadas dos respectivos nomes (ATA DO POVO PURUBORÁ, 2001).

Em relação a esse primeiro encontro, Montanha (2014) registrou:

Esse foi o primeiro reencontro das famílias do povo Puruborá depois de 40 anos de distanciamento. Nessa assembleia foi realizado o primeiro levantamento linguístico do povo feito pela linguista Ruth Maria Fonini Monserrat que, junto com os mais velhos fez um levantamento de aproximadamente 200 palavras e expressões diversas. Foi feito também um documento reivindicando $O$ território tradicional do povo (MONTANHA, 2014, p. 18).

Evidenciamos que o conceito de território utilizado nesse trabalho

${ }^{16} \mathrm{O}$ registro desta ata foi feito manuscrito. 
não é apenas o conceito político de delimitação de fronteiras e/ou o conceito de lugar que assegura a sobrevivência e o sustento dos povos indígenas por meio da caça, da pesca, da coleta de frutos, do plantio, entre outros; uma vez que a relação dos povos indígenas com o território não é uma relação fria e abstrata, mas uma relação cheia de significados para o grupo. Neste sentido, Aresi relata que

[...] a ligação do indígena com o território em que vive ou viveu é muito forte, justamente pela bagagem cultural que este possui. Embora o contato com outras culturas tenha mudado em partes o seu modo de vida, alguns aspectos culturais herdados de gerações passadas perduram de forma incisiva até os dias atuais. Este território considerado por eles sagrado, muitas vezes é o motivo de vida ou de morte deste grupo. É no território que os povos indígenas possuem seu maior campo de lutas e de resistências (ARESI, 2008, p. 2).

De acordo com o registro da $3^{\text {a }}$ assembleia do povo Puruborá, ocorrida em 2003: "Não há povo reconhecido sem o reconhecimento de sua Terra". Assim, a demarcação do território para esse povo significa mais do que dispor de um espaço do qual detenham a posse e no qual garantam a sobrevivência. Significa a revitalização de sua identidade e de sua cultura e, por isso, esse povo acompanha essa demarcação, lutando e brigando por ela. De acordo com Montanha (2014), a luta pela demarcação do território tradicional do povo Puruborá é uma de suas reivindicações mais relevantes, "[...] pois somente com a demarcação e proteção do território indígena a etnia Puruborá poderá garantir a sobrevivência material e cultural enquanto povo" (MONTANHA, 2014, p. 19). Este é um dos maiores desafios que os povos indígenas enfrentam: recuperar e garantir a demarcação dos seus territórios, que "[...] é a condição básica para a continuidade de suas vidas física e cultural, enquanto povos indígenas" (CIMI, 2013).

Neste sentido, de acordo com relatos do Cimi (2013), os povos indígenas do Brasil são vistos por muitos e muitas como entraves ao "desenvolvimento do país": "Suas terras tradicionais são cobiçadas, são usurpadas para converter em latifúndios, ou para abrigar grandes obras, como as hidrelétricas, por exemplo" (CIMI, 2013, n.p.). Ou seja, os territórios indígenas são utilizados para alimentar a ganância do sistema 
capitalista. Desta forma, para a Articulação Nacional de Educação do Cimi (CIMI-ANE, 2004), a terra é vista como mercadoria pelo sistema capitalista, mas como mãe que alimenta e protege pelos povos indígenas.

Destas condições decorrem a violência e as constantes ameaças a que os povos indígenas estão expostos, como, por exemplo, o caso, relatado pelo Cimi (2013), em que foi assassinado Samado Pataxó HãHã-Hãe, um importante líder indígena desse povo no Nordeste. No caso do povo Puruborá, embora já exista um Grupo Técnico (GT) constituído visando realizar estudos complementares necessários à identificação e delimitação da Terra Indígena (TI) Puruborá, coordenado pelo antropólogo Dr. Felipe Ferreira Vander Velden, da Universidade Federal de São Carlos (Portaria 1.061, de 11 de setembro de 2014), o processo de demarcação deste território, de acordo com Barboza (2012), não avançou, e entre as justificativas para a lentidão, as e os indígenas mencionam a falta de interesse por parte de alguns órgãos, como a Funai, a qual alega que essa morosidade deve-se a questões burocráticas. E, por isso, segundo documento reivindicatório lavrado em 22 de abril de 2005, o território puruborá atualmente está ocupado por madeireiros, fazendeiros e grileiros.

Existem alguns obstáculos para que o povo Puruborá consiga ter sua terra tradicional de volta, entre elas a ambição desmedida de certos agropecuaristas, já que Rondônia teve vários ciclos econômicos que fizeram parte do desenvolvimento regional, como o extrativismo mineral e vegetal, turismo e agricultura, mas o que predomina na atualidade é a agropecuária. Os agropecuaristas da região onde se situa a área reivindicada pelo povo Puruborá cobiçam as terras indígenas, principalmente com a sua valorização devido ao asfaltamento da BR 429. Este fator tem sido motivo de ameaças, especialmente para a cacique do povo ${ }^{17}$, mas as e os puruborá permanecem resistindo, alimentando o sonho de ter sua terra, sua dignidade respeitada e lutando para que se efetive cada reivindicação (BARBOZA, 2012; OLIVEIRA, BRITO e BIAZATTI, 2012).

\footnotetext{
${ }^{17} \mathrm{O}$ documento reivindicatório, lavrado em 22 de abril de 2005 direcionado ao presidente da Funai e assinado por Hozana e por uma liderança puruborá de Porto Velho, relatou que Hozana e um dos seus irmãos estavam sendo ameaçados.
} 
Durante o trabalho de campo aconteceu um episódio em que percebemos o quanto esse clima de ameaça afeta as relações e o dia a dia na Aldeia Aperoi:

Por volta das $12 \mathrm{~h} 50$, estava sentada na área da casa e chegou um senhor procurando por Hozana. Era a primeira vez que ele estava aparecendo na Aldeia após a minha chegada. Disse a ele que iria chamá-la. Quando eu entrava para chamar Hozana, Gisele perguntou quem era, dirigindo-se à janela da frente da casa. Respondi que era um senhor à procura de sua mãe. Gisele perguntou para o senhor o nome e o que queria. Foi até os fundos da casa, onde Hozana estava, e perguntou: "Mãe você conhece um homem com nome de Maia?". Hozana respondeu que sim. "Então vai lá na frente que ele está querendo falar contigo" - disse Gisele. Hozana disse: "É muito amigo do seu pai", dirigindo-se à frente da casa. Gisele orientou-me a não informar para qualquer pessoa que sua mãe estava em casa, pois Hozana recebia muitas ameaças de morte e para um "doido" chegar e matar sua mãe não custava nada. Disse que a Polícia Federal ficou um tempo em sua casa, por causa das ameaças devido à luta pela demarcação do seu território ${ }^{18}$, e que durante a realização de assembleias do povo é necessário contar com proteção policial (DIÁRIO DE CAMPO, 06/09/2014).

Em entrevista, Hozana relatou:

Eu trabalhava na cidade, em Seringueiras, e eu estava sendo ameaçada pelos fazendeiros. Aí fui pra Porto Velho. Fiquei em Porto Velho pra ninguém saber onde eu tava, fiquei quase, bem dizer, bem dizer não, eu fiquei escondida lá. Quatro meses trabalhando lá em Porto Velho. Aí eu achei que não tava certo eu ficar lá e minha família aqui. As minhas filhas, meu marido, ficaram aqui, minha mãe (Entrevista Hozana, 04/09/2014).

Enquanto a demarcação não é regularizada, o povo Puruborá vem denunciando a devastação: "Estamos muito preocupados com a devastação que esta ocorrendo nessa terra, que é nossa

\footnotetext{
${ }^{18} \mathrm{Na}$ ata $3^{\mathrm{a}}$ assembleia do povo, em 2003, há o registro de que as pessoas presentes comentaram acerca dos tipos de cuidado que precisariam ter para preservar as pessoas residentes da aldeia Aperoi e suas proximidades.
} 
tradicionalmente" (ATA DO POVO PURUBORÁ, 200419). Neste documento, o povo ainda questiona o que irá sobrar da terra quando ela for devolvida a ele se o Instituto Brasileiro do Meio Ambiente e dos Recursos Naturais Renováveis (Ibama) não tomar as medidas cabíveis, coibindo o desmatamento desenfreado em cumprimento às leis de proteção ambiental, denunciando que: "É o quarto ano que nos reunimos e vemos a mata ser reduzida" (ATA DO POVO PURUBORÁ, 2004).

Segundo Montanha (2014), o asfaltamento da BR 429 e as construções das linhas 20 Zero, Quatro, Sete Pontes e 22 C no município de Seringueiras geraram impactos ambientais e culturais na Aldeia Aperoi:

\begin{abstract}
Esses impactos foram: diminuição da pesca, assoreamento dos rios Manoel Correia e Cabixi, desmatamento das matas para retirada de madeira e terra, produção de lixo e contaminação do ar, do solo e da água. A usina foi construída dentro do território tradicional que o povo vem lutando para demarcar. [...] Em relação à cultura, a construção da BR 429 e das linhas $[\ldots]$, contribuiu para severa transformação do espaço tradicional, sendo que alguns lugares sagrados foram destruídos (MONTANHA, 2014, p. 19).
\end{abstract}

Atualmente, uma parte dos e das integrantes do grupo acompanha a luta por esta demarcação, que está sendo conduzida pela cacique Hozana. De acordo com ela, atualmente, na Aldeia Aperoi e zona urbana do município de Seringueiras, residem 62 indígenas desse grupo (DIÁRIO DE CAMPO, $21 / 10 / 2014)$.

Segundo Montanha (2014, p. 20), moram na aldeia 12 famílias indígenas, sendo que elas tiram seus sustentos "[...] por meio da venda do leite para os laticínios da região, trabalham por diárias para os fazendeiros locais e/ou cultivam roças de subsistência", uma vez que não podem entrar nos lugares em que faziam suas pescarias, caçadas e coletas de frutos tradicionais, entre eles, castanha, pequi, açaí e patoá, pois são proibidos e proibidas pelos fazendeiros, que atualmente estão donos desses lugares tradicionais do povo Puruborá. Percebemos,

\footnotetext{
${ }^{19} \mathrm{O}$ registro desta ata foi feito manuscrito.

${ }^{20}$ Termo muito utilizado em Rondônia para designar as estradas que cortam as propriedades rurais.
} 
durante o trabalho de campo, que as e os puruborá residentes na Aldeia Aperoi ainda mantêm a prática de pesca e caça na área em que residem, apesar da redução dos peixes e animais em função da degradação ambiental.

A situação do povo Puruborá é semelhante à das comunidades indígenas que se dispersaram na região ribeirinha do médio e baixo São Francisco, onde subsistem como camponeses, executando trabalhos eventuais nas cidades e no campo como meeiros ou prestando serviços temporários em terras arrendadas (AMORIM, 2010).

Destacamos, ainda, que, de acordo com Montanha (2014), as e os jovens indígenas puruborá saem da comunidade à procura de melhores condições financeiras, por falta da demarcação do território, provocando a desagregação familiar e gerando mais preconceitos e discriminação, uma vez que

[...] ao chegar à cidade encontram uma grande dificuldade por não terem experiências de trabalhos urbanos e sem estudos suficientes para conseguirem melhores empregos, são empregados em trabalhos que proporcionam poucas condições para uma vida digna na cidade (MONTANHA, 2014, p. 20).

Na Aldeia Aperoi, as casas são feitas de madeira, cobertas com telhas Eternit e/ou de barro. Em relação à saúde, de acordo com Montanha (2014), apesar de não existir um posto de saúde na aldeia, as e os puruborá contam com o atendimento da agente indígena de saúde "[...] e também recebem a visita mensal dos técnicos de enfermagem da Casa de Apoio ao Indígena (Casai) do polo de Jaru" (MONTANHA, 2014, p. 18).

Nas lutas por seus direitos, pela demarcação de seu território e pela revitalização da sua cultura e da identidade, um elemento utilizado pelas e pelos puruborá como aglutinador e fortalecedor da identidade do povo é a língua puruborá. Galúcio (2013) apontou essa questão e afirmou: "Os Puruborá vivem um momento histórico de luta pelo reconhecimento e valorização de sua identidade indígena e de retomada de sua terra tradicional. A valorização da cultura e da língua tradicional é uma etapa importante desse processo" (GALÚCIO, 2013, p. 5).

De acordo com Monserrat (2002) e Galúcio (2005), a língua 
puruborá é uma língua isolada dentro do tronco Tupi. Monserrat (2002), como uma das conclusões preliminares relacionada ao seu estudo, afirmou que

[...] trata-se de uma língua praticamente extinta, mas, apesar disto, mantêm-se as características fonéticas mais salientes do grupo Tupi em comparação com o português: vogal posterior alta não arredondada, oclusivas finais não explodidas, oclusão glotal, oclusiva bilabial surda pré-nasalizada (MONSERRAT, 2002, p. 9).

Embora a língua puruborá esteja praticamente extinta do ponto de vista linguístico (MONSERRAT, 2002), ela é vista pelas e pelos participantes da pesquisa como língua materna. Entretanto, a língua portuguesa é a língua materna desse povo (MONSERRAT, 2002), que foi proibido de manifestar-se culturalmente, conforme denunciam as e os puruborá em suas atas anuais. "Paulo Poreti relata que o Inspetor do SPI, Capitão José Félix do Nascimento, impediu a dança, o canto, ritos, mitos e pintura dos povos Puruborá e Miqueleno, Cabixi e Aruá". Ainda, segundo o mesmo registro, a língua também foi proibida. "O chefe do SPI, José Felix do Nascimento, subimeteu nossos avós como seringueiros, proibiu nosso povo de falar nossa língua" (ATA DO POVO PURUBORÁ, 2004).

O trabalho de Ramirez (2006) relata que há dois falantes dessa língua na região do Rio São Miguel. Hozana afirmou que atualmente há seis falantes da língua puruborá, sendo que Mário e Deivid, moradores próximos da Aldeia Aperoi, são os falantes mais novos, e os falantes anciãos são Nilo e Eliézer, moradores em Guajará-Mirim, Celestino, morador em Porto Murtinho (município de São Francisco do Guaporé) e Paulo Aporete, morador em Costa Marques (DIÁRIO DE CAMPO, 12/02/2015).

Embora durante o trabalho de campo não tenhamos presenciado nenhum indígena se comunicando na língua puruborá, utilizando-se para isso exclusivamente a língua portuguesa, constatamos que com as e os puruborá ocorre o mesmo processo apontado por Freitas (2003) com as e os indígenas makuxi. Eles se consideram falantes da língua tradicional "[...] por entenderem ou falarem algumas palavras, não 
significando necessariamente usar a língua como veículo de comunicação" (FREITAS, 2003, p. 104). Assim, percebemos que as e os participantes de nossa pesquisa consideram como falantes as pessoas mais velhas do grupo que já utilizaram ativamente a língua quando jovens, além dos professores Mário e Deivid, que são os que mais conhecem palavras e frases nessa língua, especialmente Mário, que a estuda há aproximadamente 11 anos.

Outro ponto importante a ser destacado é que a língua puruborá ganha centralidade quando esse povo se refere a sua cultura. Podemos compreender, conforme explica Freitas (2003, p. 88), que "A língua e, ainda mais, o direito a ela, parece funcionar como um ícone, um símbolo, que só poderá ser entendido se relacionado à preservação, identitária e, em última instância, territorial".

Esta centralidade cultural da língua para o povo Puruborá parece ser uma das características das e dos indígenas ressurgidos, uma vez que precisam dar visibilidade aos elementos que fortaleçam a identidade indígena, embora, em muitos casos, e especialmente no caso desse povo, a língua indígena tenha sido praticamente extinta, restando-Ihes apenas algumas palavras e algumas frases.

Esse povo indígena apoia-se na língua puruborá como marca de sua cultura, como símbolo de sua identidade indígena e como forma estratégica e política de luta diante da população não indígena, bem como da comunidade indígena rondoniense. A situação do povo Puruborá se aproxima à do povo Makuxi estudado por Freitas (2003, p. 105), para o qual "saber falar, alguma coisa ao menos, ou entender, é suficiente. A língua como algo que se tem, que pode ser mostrado para assim comprovar algo que se é, no caso, índio Makuxi".

Entretanto, Pereira (2003) alerta para o lado negativo de perceber a língua indígena como elemento identitário, uma vez que leva alguns povos que "perderam" sua língua tradicional há mais de 300 anos, a buscá-la como um elo perdido, vendo nessa língua a única forma de se salvarem enquanto povos indígenas.

Segundo relatos de Catheu (2002), após a localização das famílias do povo Puruborá na região do Rio Manoel Correia, ocorreu o primeiro encontro com esse povo, onde esteve presente Ruth Monserrat, professora de linguística da UFRJ, que levantou um acervo de 200 
palavras com alguns idosos do grupo. Monserrat (2002) afirmou que esse encontro ocorreu no mês de outubro de 2001, sendo a primeira vez que se reuniram depois de muitos anos. A autora (2002) trouxe um breve histórico do povo, a transcrição fonética de palavras do vocabulário puruborá, além das pessoas participantes desse trabalho.

De acordo com Galúcio (2005, p. 162): "Os únicos trabalhos de que se tem notícia sobre a Língua Puruborá são listas de dados lexicais coletadas em diferentes épocas do século XX". A primeira lista foi composta por 328 vocábulos subdivididos em áreas semânticas, elementos da natureza, partes do corpo humano, manufaturas e casa, que foi coletada por Theodore Kock-Grüberg (1932) com um jovem puruborá entre dez e doze anos na cidade de Manaus, mas oriundo da região do Rio Manoel Correia (GALÚCIO, 2005).

A segunda lista é composta por 49 palavras e foi coletada por Willian Bontkes (1968) com uma senhora puruborá na localidade de Limoeiro, região do Rio São Miguel. Trata-se do vocabulário padrão do Museu Nacional. A terceira lista foi gravada e é composta por 130 palavras, sendo coletada pelo linguista do Museu Paraense Emílio Goeldi, Denny Moore, em 1989 com três remanescentes puruborá e suas famílias no município de Guajará-Mirim (GALÚCIO, 2005). Além destas listas, citadas por Galúcio (2005), tem-se disponível uma lista com 84 palavras da língua puruborá, coletadas e registradas no diário do Dr. E. H. Snethlage, em 8 de fevereiro de 193421.

A pesquisa de Galúcio (2005) contribuiu na coleta de dados que possibilitou a composição do corpus lexical de 700 vocábulos, composto por palavras e algumas frases. De acordo com a autora (2005, p. 163), os dados: "[...] foram coletados inicialmente [...] nas cidades de Guajará Mirim e Costa Marques, no estado de Rondônia. Serviram como principais informantes dois anciãos Puruborá de aproximadamente 70 e 80 anos [...]". Segundo relatos de Galúcio (2005), os dois informantes lembraram e disseram as palavras com clareza e na maioria das vezes sem titubeação e, ainda, foram falantes ativos da língua quando jovens.

Embora Galúcio (2005) não tenha citado o trabalho de Ruth Monserrat (2002), acreditamos ser indispensável mencioná-lo no

\footnotetext{
${ }^{21}$ Disponível em: http://etnolinguistica.wdfiles.com/local--files/emil\%3A4/borobura transcription.pdf. Acesso em: 11 mar. 2015.
} 
presente artigo, uma vez que, durante o trabalho de campo, Hozana, Gisele e seu pai se referiram em dois momentos a Monserrat com respeito e gratidão.

O primeiro momento se deu quando Gisele, Hozana e a autora principal do presente trabalho estavam sentadas em volta da mesa da cozinha da casa delas e Gisele comentou que conheceu Ruth Monserrat no encontro de professores e lideranças indígenas do estado de Rondônia, em Pimenta Bueno, onde ela participou, indagando à pesquisadora se ela a conhecia. Após a pesquisadora responder que não, Gisele disse que Ruth Monserrat foi a primeira pessoa a fazer o trabalho de resgate da língua materna e relatou que ela, ao concluir o trabalho, o entregou para o Cimi (DIÁRIO DE CAMPO, 28/08/2014).

$O$ segundo momento foi no dia em que a pesquisadora foi com o esposo de Hozana e um dos sobrinhos dele conhecer a mata na fundiária da aldeia e, também, pescar com eles. Durante o trajeto de volta, o esposo de Hozana relatou sobre a fartura de caça que havia no lugar e que no primeiro estudo sobre o povo e a demarcação do seu território realizado por Ruth Monserrat, o grupo chegou justamente no dia em que ele havia matado alguns porcos do mato, e como ela estava acompanhada de pessoas que trabalhavam no Ibama e na Polícia Federal, ele ficou temeroso de chegar com aquela caça. Por isso, deixou a caça na beira do rio e foi dialogar com Hozana, que, ao conversar com Ruth Monserrat, não se opôs, ao contrário, dispôs-se a ajudá-lo (DIÁRIO DE CAMPO, 10/09/2014).

Além desses momentos vividos durante o trabalho de campo, em documento pessoal de Hozana, encontramos referência à pesquisadora. Hozana descreve uma breve história de sua família e menciona o nome de Gil Catheu, da professora Ruth Monserrat e de outras pessoas do Cimi, agradecendo-as por proporcionarem o primeiro encontro do povo Puruborá.

O trabalho de Galúcio também precisa ser destacado, uma vez que, em 2013, com a ajuda de dois anciãos puruborá, publicou um livro intitulado Vocabulário Ilustrado - animais na Língua Puruborá, que se constitui em material didático diferenciado e está sendo utilizado nas aulas de língua puruborá na escola deste povo.

$\mathrm{Na}$ apresentação ao material, Galúcio (2013) afirma que 
O Vocabulário ilustrado - animais na Língua Puruborá é o primeiro material didático de apoio à alfabetização na língua tradicional do povo indígena Puruborá. Este vocabulário foi organizado com base no material produzido pelo projeto de documentação e estudo da língua, que vem sendo desenvolvido desde 2001 por Ana Vilacy Galúcio, e que conta com a colaboração imprescindível de Paulo Aporete Filho e José Evangelista Puruborá, como principais colaboradores e consultores neste trabalho. Esta é, portanto, uma obra conjunta dos autores que documentaram e sistematizaram 0 conteúdo e destina-se especialmente ao uso dos Puruborá (GALÚCIO, 2013, p. 5, destaque no original).

A autora (2013, p. 6) mencionou que o livro também é resultado de uma última revisão realizada na escola indígena do povo Puruborá, na Aldeia Aperoi, em janeiro de 2012, junto ao professor Mário "[...] com base nas discussões realizadas com os alunos, a partir do uso da ortografia proposta." De acordo com a autora (2013, p. 5), o objetivo do livro é: "[...] subsidiar o trabalho de alfabetização na Língua Puruborá22 e ajudar na motivação dos Puruborá em aprender um pouco da língua tradicional do seu povo, a partir do que é ainda lembrado pelos anciões".

Entre os dias 16 e 18 de dezembro de 2013 aconteceu uma reunião de trabalho proposta pela Funai na Aldeia Aperoi para verificar a questão da fundação da associação do povo Puruborá, do estudo da língua e da questão do resgate e tradições culturais. Nessa reunião, esteve presente um linguista da Unir para realizar um trabalho com o professor Mário, visando selecionar os pronomes da língua e classes das palavras, com a ajuda de uma professora da Funai (ATA DE REUNIÃO DA FUNAI, 201323).

No primeiro dia de reunião, Mário, ao se apresentar, mencionou a importância desse trabalho da língua e também "[...] vários Puruborá falaram sobre a importância deste trabalho da língua e do resgate da tradição cultura [...]". No último dia dessa reunião, o linguista da Unir

\footnotetext{
${ }^{22}$ Embora o Vocabulário Ilustrado - Animais na Língua Puruborá esteja sendo utilizado nas aulas de língua na escola desse povo, é importante destacar que, no momento, ele não está subsidiando o trabalho de alfabetização na língua puruborá, já que esse trabalho na escola do povo Puruborá acontece em língua portuguesa.

${ }^{23} \mathrm{O}$ registro desta ata foi digitado.
} 
relatou que Galúcio fez um trabalho muito bom e que não resta dúvida da contribuição e desempenho dela, mas ressaltou que ainda falta concluir a questão da escrita (ATA DE REUNIÃO DA FUNAI, 2013). Assim, o linguista

[...] colocou a questão da parte gramática e mostrou a normatização de alguns grafemas e disse que nada será modificado sem o consentimento e autorização da comunidade. O professor Mario, da língua materna fazendo uso da palavra, disse que são algumas letras que devemos substituir por outras devido não ter no computador que é para facilitar a aprendizagem, mas que vamos mostrar mas quem decide é a comunidade (ATA DE REUNIÃO DA FUNAI, 2013, destaque no original).

Durante o trabalho de campo presenciamos uma situação em que o professor Mário explicou os sons das letras na língua puruborá para o chefe de núcleo de educação escolar indígena ${ }^{24}$ e um primo de Gisele que visitavam a escola. Informou, ainda, que a comunidade decidiu trocar algumas letras porque o computador não tinha a grafia da letra $u$ cortada ao meio, sendo necessária a substituição pelo 'y' e o ' $y$ ' pelo 'j' (REGISTRO AMPLIADO, 08/09/2014).

Assim, percebemos que a história do povo Puruborá, seu ressurgimento e resistência estão entrelaçados por suas lutas pela revitalização da sua cultura e de sua identidade e pela demarcação de seu território.

\section{CONSIDERAÇÕES FINAIS}

O "mito de extinção", sustentado especialmente pela "mistura" e "miscigenação" dos povos indígenas, foi uma das estratégias utilizadas pelos e pelas não indígenas para justificarem a apropriação dos seus territórios. Ao proibirem aos indígenas suas identidades e culturas, obrigando-os a "serem" e "viverem" como não indígenas, teriam argumentos que poderiam sustentar essa apropriação.

\footnotetext{
${ }^{24} \mathrm{O}$ chefe foi neste dia à escola para entregar um pouco de merenda e ficou observando a aula de Gisele e de Mário por alguns minutos.
} 
Para garantirem ao menos suas sobrevivências físicas, as populações indígenas brasileiras se viram obrigadas a ocultar suas identidades, vivendo como se não fossem indígenas, durante o longo contexto histórico que orquestrava essa complexa situação.

O momento atual, resultado da organização e luta desse povo, caracteriza-se como mais favorável às populações indígenas que a partir da Constituição federal de 1988 e de outros marcos, como, por exemplo, a convenção e resolução 169/1989 da Organização Internacional do Trabalho (OIT), sentiram-se empoderados para assumirem suas identidades e prosseguir de forma mais intensa a luta pelos seus direitos. Após 488 anos de proibições, mas de sobrevivência, luta e resistência, as populações indígenas brasileiras estão presenciando 27 anos de direitos. No entanto, não sem grande mobilização e participação efetiva, especialmente a partir da década de 1980.

Percebemos que os termos indígenas "ressurgidos", "emergentes" e "resistentes" têm sido um campo de polêmicas discussões, considerando que não há neutralidade em nenhum termo. Nesse sentido, conforme discussão realizada na primeira parte deste artigo, consideramos as e os puruborá como "ressurgidos" e "resistentes".

Entendemos o termo "ressurgido" como o primeiro passo de uma grande luta que é empreendida pelos povos indígenas considerados desaparecidos para se darem a conhecer como indígenas. Desta forma, o povo Puruborá é um povo ressurgido, como eles mesmos se autorreconhecem.

Consideramos que a denominação "resistentes" é adequada ao se referir ao povo Puruborá, porque a sua identidade indígena sempre esteve presente, e, apesar dos ataques sofridos, sobreviveram à proibição de serem indígenas. Assim, após o ressurgimento, ocorrido no ano de 2000 , as e os puruborá reagruparam-se, organizaram-se e estão na luta pelo fortalecimento de suas identidades e para acessar seus direitos, entre eles, a demarcação da terra.

Por isso, visualizamos o povo Puruborá como um exemplo de resistência, especialmente quando recorremos ao conceito de André:

[...] um conjunto de práticas, exercidas por grupos subordinados, que se expressam sob a forma de 
oposição, numa tentativa de barrar a dominação, de não perder sua identidade e seus costumes. São os comportamentos contraditórios e ambíguos e as situações conflituosas, presentes na realidade social, que permitem que tal resistência apareça (ANDRÉ, 1988 , p. 36).

A história do povo Puruborá está fundamentada em "formas cotidianas de resistência", o que, segundo Ferreira (2007, p. 18, destaque no original), "[...] é uma forma de luta de classes, que exige pouca ou nenhuma coordenação, e que se viabiliza por uma série de 'técnicas': sabotagem, dissimulação, furto e etc.". Entre as formas cotidianas de resistência deste povo, destacamos suas formas de organização e reivindicação, bem como as estratégias criadas para conseguir o que precisam. Por exemplo, ainda não conseguiram a demarcação oficial da sua terra tradicional, mas compraram um pedaço dela para se reunirem.

Assim, o momento histórico, político e social que o povo Puruborá está vivendo, do "ressurgimento", da resistência indígena por meio da participação no movimento indígena e em outras situações de luta pelos seus direitos (território, saúde, educação etc.) e da revitalização das práticas culturais e tradicionais (especialmente no ambiente escolar), tem sido muito favorável para a revitalização, (re)construção e para o fortalecimento da identidade dos indígenas, enquanto indivíduos e também enquanto povo.

\section{Referências bibliográficas}

ALBUQUERQUE, Manuel Coelho. Pelos direitos de ser índio: artes e atitudes educativas. In: I Encontro Internacional de Direitos Culturais. Universidade de Fortaleza, 2012. Disponível em: http://www.direitosculturais.com.br/ojs/index.php/articles/article/view/77/62. Acesso em: 10 out. 2013.

AMORIM, Siloé Soares de. Índios ressurgidos: a construção da auto-imagem os tumbalala - Os Kalankó, os Karuazu, os Catókinn e os Koiupanká. 2003, 301 f. Dissertação (Mestrado em Multimeios) - Universidade Estadual de Campinas, [2003]. 
Os Kalankó, Karuazu, Kaoipanká e Katokinn: resistência e ressurgência indígena no Alto Sertão alagoano. 2010, 431 f. Tese (Doutorado em Antropologia Social) - Universidade Federal do Rio Grande do Sul, [2010].

ANDRÉ, Marli Eliza Dalmazo Afonso de. O repensar da didática a partir do estudo da dominação e resistência no cotidiano escolar. R. Fac. Educ., São Paulo, v. 14, n. 1, p. 35-41, 1988.

ARAÚJO, Vera Lúcia Soares de. Educação, identidade e cidadania: uma leitura da ação política do povo "ressurgido" Aranã. 2011, 94 f. Dissertação (Mestrado em Educação) - Universidade do Oeste Paulista, Presidente Prudente, SP, [2011].

ARESI, Cláudia. O território como suporte identitário para a cultura kaingang. CampoTerritório, Rio de Janeiro, v. 3, n. 5, p. 264-279, 2008. Disponível em: http://www.redesrurais.org.br/sites/default/files/o\%20territ\%c3\%93rio\%20como\%20su porte\%20identit\%c3\%81 rio\%20para\%20a\%20cultura\%20kaingang.pdf. Acesso em: 15 out. 2012.

ARRUTI, José Maurício Andion. Morte e vida do nordeste indígena: a emergência étnica como fenômeno histórico regional. Estudos Históricos, Rio de Janeiro, v. 8, n. 15, p. 57-94, 1995.

A emergência dos "remanescentes": notas para o diálogo entre indígenas e quilombolas. Mana, Rio de Janeiro, v. 3, n. 2, p. 7-38, 1997.

BARBOZA, José Joaci. Puruborá: narrativas de um povo ressurgido na Amazônia. In: XI Encontro Nacional de História Oral, Rio de Janeiro, 2012, Instituto de Filosofia e Ciências Sociais/Instituto de História da Universidade Federal do Rio de Janeiro. Disponível em: http://www.encontro2012.historiaoral.org.br/resources/anais/3/1339991713_ARQUIVO _PuruboraNarrativasdeumPovoRessurgidonaAmazonia.pdf. Acesso em: 08 ago. 2013.

BIAZATTI, Suzana das Candeias; OLIVEIRA, Anatália Daiane de; BRITO, Claudineia Gomes. Povo Puruborá: a relação dos indígenas com os seus idosos. In: Anais do VI Seminário de Educação, Ji-Paraná, RO, 2013, Universidade Federal de Rondônia.

BOGDAN, Robert; BIKLEN, Sari. Investigação qualitativa em Educação: uma introdução à teoria e aos métodos. Porto: Porto Editora, 1994.

BRASIL. Portaria $\mathrm{n}^{\circ} 1.061$, de 11 de setembro de 2014. Diário Oficial da União, $\mathrm{n}^{\circ}$ 176, 12 set. 2014.2 Disponível em: http://pesquisa.in.gov.br/imprensa/jsp/visualiza/index.jsp?jornal=2\&pagina=48\&data $=1$ 2/09/2014. Acesso em: 07 out. 2014.

CASSIMIRO, Poliana Alves; BARBOZA, José Joaci. Grupo de Pesquisa em Educação da Amazônia - GPEA: Puruborá um povo indígena resgatando sua identidade e cultura. Revista Pesquisa \& Criação, Porto Velho, v. 11, p. 316-322, 2012. 
CATHEU, Gil de. Puruborá: mais um povo ressurgido em Rondônia. Conselho Indigenista Missionário de Rondônia (CIMI-RO), 2002. Disponível em: http://pib.socioambiental.org/en/noticias?id=4615. Acesso em: 16 mar. 2014.

CIAMPA, Antonio da Costa. Políticas de Identidade e Identidades Políticas. In: DUNKER, Christian Ingo Lenz; PASSOS, Maria Consuêlo (Org.). Uma Psicologia que se interroga: ensaios. São Paulo: Edicon, 2002. p. 133-144.

Identidade. In: LANE, Silvia Tatiana Maurer; CODO, Wanderley (Org.).

Psicologia Social: o homem em movimento. São Paulo: Brasiliense, 2004. p. 58-75.

CONSELHO INDIGENISTA MISSIONÁRIO (CIMI). Juventude indígena em busca de seu protagonismo. Brasília: CIMI, 2013. Não paginado.

CIMI-ANE (Articulação Nacional de Educação). Memória e Resistência: a sabedoria dos povos indígenas. 2004.

CONSELHO DE MISSÃO ENTRE POVOS INDÍGENAS (COMIN). Povo PuruboráRO se organiza para resgatar sua identidade e reconquistar suas terras tradicionais. 2007. Disponível em: http://comin.org.br/noticias/noticia/id/90. Acesso em: 22 jul. 2015.

FERREIRA, Andrey Cordeiro. Ordem e Anarquia na Sociologia: percepções da mudança social e luta política. In: Tutela e Resistência Indígena: etnografia e história das relações de poder entre os Terena e o Estado brasileiro. 2007. 420 f. Tese (Doutorado em Antropologia Social do Museu Nacional) - Universidade Federal do Rio de Janeiro, Rio de Janeiro, [2007]. p. 16-55.

FREIRE, Paulo. Pedagogia da esperança: um reencontro com a Pedagogia do oprimido. Rio de Janeiro: Paz e Terra, 1993.

FREITAS, Déborah de Brito Albuquerque Pontes. Escola Makuxi: identidades em construção. 2003. 234 f. Tese (Doutorado em Linguística Aplicada) - Universidade Estadual de Campinas, Instituto de Estudos da Linguagem, Campinas, SP, [2003].

GALÚCIO, Ana Vilacy. Puruborá: notas etnográficas e lingüísticas recentes. Boletim do Museu Paraense Emílio Goeldi. Belém, v. 1, n. 2, p. 159-192, 2005.

Introdução. In: GALÚCIO, Ana Vilacy; PURUBORÁ, José Evangelista; APORETE FILHO, Paulo (Org.). Vocabulário ilustrado: animais na Língua Puruborá. Belém: MPGE, 2013. p. 5-7.

LEONEL, Mauro. Etnodicéia Uruéu-au-au: o endocolonialismo e os índios no centro de Rondônia, o direito à diferença e à preservação ambiental. São Paulo: Editora da USP/Instituto de Antropologia e Meio Ambiente/ FAPESP, 1995.

MAHEIRIE, Kátia. Constituição do sujeito, subjetividade e identidade. Interações, São Paulo, v. 7, n. 13, p. 31-44, 2002. 
MONSERRAT, Ruth Maria Fonini. Notícia sobre a Língua Puruborá. In: XVII Encontro da ANPOL, Gramado, RS, 2002.

MONTANHA, Gisele de Oliveira. História tradicional do povo Puruborá: narrativas na escola indígena Ywará Puruborá. 2012. Manuscrito.

Mitos do povo Puruborá. 2014. 37 f. Monografia (Graduação em Licenciatura em Educação Básica Intercultural) - Fundação Universidade Federal de Rondônia, JiParaná, RO, [2014].

MONTANHA, Gisele de Oliveira; BARBOZA, José Joaci. Mitos do povo Puruborá. In: Anais do VI Seminário de Educação, Ji-Paraná, RO, 2013, Universidade Federal de Rondônia.

OLIVEIRA, João Pacheco de. Uma etnologia dos "índios misturados"? Situação colonial, territorialização e fluxos culturais. Mana, do Rio de Janeiro, v. 4, n. 1, p. 4777, 1998. Disponível em: http://www.scielo.br/pdf/mana/v4n1/2426.pdf. Acesso em: 7 abr. 2012.

OLIVEIRA, Ovídio Amélio de. História: Desenvolvimento e Colonização do Estado de Rondônia. Porto Velho: Dinâmica Editora e Distribuidora Ltda, 2007.

OLIVEIRA FILHO, João Pacheco de. A problemática dos "índios misturados" e os limites dos estudos americanistas: um encontro entre antropologia e a história. In: $\overline{99-123 .}$

Ensaios em antropologia histórica. Rio de Janeiro: Editora UFRJ, 1999a. p.

Entrando e saindo da "mistura": os índios nos censos nacionais. In:

Ensaios em antropologia histórica. Rio de Janeiro: Editora UFRJ, 1999b. p. 124-151.

OLIVEIRA, Anatália Daiane de; BRITO, Claudineia Gomes; BIAZATTI, Suzana das Candeias. Percepção de território para o povo Puruborá: Alguns apontamentos. In: XXX Semana de Geografia. I Encontro Internacional de Geografia, Porto Velho, 2012. Disponível em https://www.dropbox.com/s/v54eh273azhx5id/artigo\%20percepa\%C3\%A7\%C3\%A3o. pdf?m. Acesso em: out. 2013.

PEREIRA, Veronica Mendes. A cultura na escola ou escolarização da cultura? um olhar sobre as práticas culturais dos índios Xacriabá. 2003. 138 f. Dissertações (Mestrado em Educação) - Universidade de Minas Gerais, Belo Horizonte, [2003].

PORTELA, Cristiane de Assis. Nem ressurgidos, nem emergentes: a resistência histórica dos Karajá de Buridina em Aruanã-GO (1980-2006). 2006. 233 f. Dissertação (Mestrado em História) - Universidade do Oeste Paulista, Goiânia, GO, [2006].

PREZIA, Benedito; HOORNAERT, Eduardo. Os povos indígenas emergentes. In: Brasil Indígena: 500 anos de resistência. São Paulo: FTD, 2000. p. 89-97. 
RAMIREZ, Henri. As línguas indígenas do Alto Madeira: estatuto atual e biografia básica. Língua viva, Porto Velho, v. 1, n. 1, p. 1-16, 2006.

SANTOS, Boaventura de Sousa. Modernidade, identidade e a cultura de fronteira. In: Pela mão de Alice: o social e o político na pós-modernidade. São Paulo: Cortez, 2010. p. 135-157.

SANTOS, Vanúbia Sampaio dos. Expressões identitárias no espaço escolar: um estudo com estudantes indígenas de escolas públicas urbanas de Ji-Paraná, Rondônia. 2014. 155 f. Dissertação (Mestrado em Educação) - Universidade Federal de Mato Grosso, Cuiabá, [2014].

SAWAIA, Bader Burihan. Comunidade como Ética e Estética: Uma Reflexão Mediada pelo Conceito de Identidade. Psykhe, Santiago, Chile, v. 8, n. 1, p. 19-25, 1999. Disponível em: http://www.psykhe.cl/index.php/psykhe/article/view/384/364. Acesso em: 13 mar. 2015.

Identidade: uma ideologia separatista? In: SAWAIA, Bader Burihan (Org.). As artimanhas da exclusão: análise psicossocial e ética da desigualdade social. Petrópolis: Vozes, 2001. p. 119-127.

SILVA FILHO, Gerino Alves da. Toponímia de Rondônia (Gentílicos). Revista Brasileira de Geografia, Rio de Janeiro, v. 57, n. 3, p. 39-61, 1995.

TEIXEIRA, Marco Antônio Domingues; FONSECA, Dante Ribeiro da. História Regional: Rondônia. Porto Velho: Rondoniana, 2003.

Recebido em: 24/12/2015* Aprovado em: 16/05/2016 * Publicado em: 30/06/2016 